\title{
Skutki podatkowe przekształcenia spółki osobowej w inną spółkę osobową
}

\begin{abstract}
Rafat Bernat*
Handlowe spótki osobowe to spótka jawna, partnerska, komandytowa, komandytowoakcyjna. Wspólnicy spótki, wybierając - przy podpisywaniu aktu erekcyjnego - dany model prowadzenia dziatalności gospodarczej, decyduja m.in. o swojej odpowiedzialności za zobowiazania spótki, partycypacji $w$ zysku $i$ stracie, przedmiocie działalności oraz o wysokości wkładów pieniężnych (lub niepieniężnych). Aby zmienić rodzaj spółki, można przeprowadzić proces przeksztatcenia $w$ spótkę osobowa lub kapitatowa (sp. z o.o. i s.a.). Oznacza to jednak dokonywanie czynności prawnych, których charakter nie jest do końca zdefiniowany na gruncie podatku od towarów i ustug, od czynności cywilnoprawnych czy podatku dochodowego od osób fizycznych. Warto rozważyć, czy przeksztatcenie spótki osobowej w inna spótkę osobowa może być neutralne podatkowo, a jeśli ma wystapić podatek - to jak określić jego elementy (przedmiot, stawka, podstawa opodatkowania). Przepisy ustaw podatkowych nie stanowia w sposób kategoryczny - w stosunku, do których czynności spótka jest podatnikiem lub ptatnikiem. Niniejsze opracowanie stanowi analize naukowa obowiąujacych $w$ tym zakresie poglądów występujących $w$ doktrynie prawa podatkowego i prawa spótek handlowych. Potrzeba przeprowadzenia takiego badania wynika także $z$ tego, że zarówno $w$ interpretacjach indywidualnych, jak i orzecznictwie sadowo-administracyjnym kwestia opodatkowania przekształcenia $w$ większości omawiana jest $w$ odniesieniu do zamiany formy prawnej spótki osobowej na spótkę kapitatowa.
\end{abstract}

Słowa kluczowe: spółka osobowa, przekształcenie, podatek od czynności cywilnoprawnych.

Nadesłany: 2.09.2014 | Zaakceptowany do druku: 13.03.2015

\section{Tax effects of converting the partnership into other partnership}

Commercial partnerships is a general partnership, professional partnership, limited partnership, joint-stock company. Partners of the company by selecting-at the time of signing of the erection act-the business model, choose inter alia about his responsibility for the liabilities of the company, participation in profit and loss, on the activities and the financial contributions (or in kind). To change the type of company you can carry out the process of transformation of a person, or holding company (limited liability company, joint stock company). This means, however, making legal transactions, the nature of which is not defined on the basis of the tax on civil law transactions of goods and services or income tax from natural persons. You might want to consider whether to convert a partnership in person may be fiscally neutral - and if it is wanted to apply this tax - how to determine its elements (item, rate, taxable). Tax laws are not as categorical - in respect of which operations the company is taxable or liable. This publication provides scientific analysis of the laws in force in this respect, the views contained

Mgr Rafal Bernat - doradca podatkowy, doktorant w Katedrze Prawa Finansów Publicznych, Wydział Prawa i Administracji, Uniwersytet Mikołaja Kopernika w Toruniu.

Adres do korespondencji: Katedra Prawa Finansów Publicznych Wydział Prawa i Administracji, Uniwersytet Mikołaja Kopernika w Toruniu, ul. Władysława Bojarskiego 3, 87-100 Toruń; e-mail: rafalbernat@onet.eu. 
in the doctrine of tax law and company law. The need to carry out that examination results also from the fact that both the individual interpretations and administrative jurisprudence the issue of taxation of transformations in the vast majority of this is in relation to convert the legal form of a partnership on a capital company.

Keywords: partnership, transformation of a company, civil law transactions tax.

Submitted: 2.09.2014 | Accepted: 13.03.2015

JEL: K20, K30, K34

\section{Wstęp}

Przedsiębiorca ma możliwość prowadzenia działalności gospodarczej w ramach jednoosobowej działalności, spółki cywilnej lub spółki prawa handlowego. Decyzja o wyborze formy działalności należy wyłącznie do przedsiębiorcy ${ }^{1}$ - to on ponosi odpowiedzialność (pełną lub ograniczoną) za niepowodzenie swojego przedsięwzięcia gospodarczego. Ponadto musi zdecydować, czy podmiot gospodarczy zostanie utworzony przez przedsiębiorcę od podstaw, czy też będzie wykorzystana dotychczasowa forma działalności. Dla potrzeb tego artykułu należy definiować przekształcenie jako zmianę dotychczasowej formy prawnej spółki handlowej w inną spółkę prawa, przy jednoczesnej sukcesji generalnej praw i obowiązków oraz ciągłości zdolności prawnej. Wskutek tego nie powstaje nowy podmiot, lecz zmianie ulega forma prawna dotychczasowej działalności. Należy zauważyć, że tylko w stosunku do niektórych rodzajów przedmiotowego procesu można odnaleźć poglądy podnoszone w doktrynie prawa podatkowego oraz $\mathrm{w}$ licznych interpretacjach indywidualnych organów podatkowych ${ }^{2}$. Wynika to $\mathrm{z}$ występowania dużej liczby tych spółek i możliwości preferencyjnego opodatkowania przekształcenia spółki kapitałowej w kapitałową na gruncie podatku od czynności cywilnoprawnych (dalej także jako PCC). Spółki osobowe, jako prostsza forma spółki handlowej, były jednak w przeszłości często wybierane przez małżonków, przedstawicieli wolnych zawodów, członków tej samej rodziny. Obecnie spółki jawne oraz partnerskie nie wydają się podmiotami gospodarczymi zapewniającymi właściwą ochronę majątków osobistych wspólników przed wierzycielami spółki. Naturalnym rozwiązaniem zdaje się zmiana dotychczasowej działalności (w ramach spółki osobowej) na inną formę gospodarczą - np. spółkę komandytową. W takim wypadku niektórzy ze wspólników stają się komandytariuszami i ograniczają swoją odpowiedzialność tylko do sumy komandytowej (wartości określonej pomiędzy wspólnikami). Warto zatem zastanowić sie jak zmienia się sytuacja prawna wspólników w związku z przekształceniem na gruncie prawa podatkowego. Taki proces może być powodem wątpliwości - czy aby przekształcenie spółki osobowej w inną spółkę osobową nie stanowi dużego obciążenia podatkowego. Celem artykułu jest odpowiedź na pytanie, czy przekształcenie spółki osobowej w inną osobową może być neutralne podatkowo. $\mathrm{Na}$ to pytanie można uzyskać odpowiedź jedynie poprzez wnikliwą (wielopłaszczyznową) analizę naukową przepisów o podatku dochodowym, podatku od czynności cywilnoprawnych i podatku od towarów i usług.

\section{Charakter prawny przekształcenia spółki osobowej w osobowa}

W piśmiennictwie wyróżnia się przekształcenie w rozumieniu sensu stricto (zmiana formy prawnej przy jednoczesnej kontynuacji istnienia podmiotu) oraz sensu largo (zmiana formy prawnej także przez likwidację, upadłość, rozwiązanie, aport przedsiębiorstwa spółki przekształcanej do innej spółki) ${ }^{3}$. Ustawodawca dokonał podziału w Kodeksie spółek handlowych ${ }^{4}$ czynności modyfikujących formę prawną spółki handlowej na: połączenie (dział I), podział (dział II) i przekształcenie (dział III). Przekształcenie sensu largo można podzielić na: uregulowane dla każdej spółki odrębnie (przepisy o likwidacji, upadłości, rozwiązaniu) oraz uniwersalne 
dla spółek osobowych lub kapitałowych (aport przedsiębiorstwa ${ }^{5}$ ). Należy postawić tezę, że w wyniku przekształcenia w rozumieniu sensu largo w sposób istotny zmieniają się prawa wspólników lub struktura przedsiębiorstwa spółki. Natomiast przekształcenie sensu stricto (także wedle gramatycznej wykładni przepisów o podziale, połaczeniu) nie oznacza, że majatek spółki ulegnie zmianie i nastąpi pomniejszenie przysługujących wspólnikom praw udzialowych.

Przekształcenie spółki prawa handlowego stanowi jeden $\mathrm{z}$ najbardziej skomplikowanych procesów opisanych w Kodeksie spółek handlowych. Poświęcono mu ponad czterdzieści artykułów Działu III k.s.h. Przekształcenie spółki osobowej w osobową zostało natomiast zawarte w czterech jedynie przepisach (art. 581-584 k.s.h.). Przekształcenie uproszczone występuje, gdy przekształceniu w spółke osobowa ulega spółka jawna lub partnerska, w której wszyscy wspólnicy prowadzili sprawy spółki przekształcanej6. Wtedy wystarcza, aby wspólnicy sporządzili plan przekształcenia podjęli uchwałę o przekształceniu 7 i podpisali umowę nowej spółki (art. 582, 558 par. 2 pkt. 1 i 2 k.s.h.). Brak licznych wymogów formalnych tego procesu ma ułatwić zmianę formy prawnej spółkom jawnym oraz partnerskim, które są coraz rzadziej wybierane ze względu na nieograniczoną odpowiedzialność wspólników). Jak to zostało już wspomniane na wstępie, część ze spółek partnerskich to podmioty założone ponad kilkanaście lat temu przez przedstawicieli wolnych zawodów (m.in. radców prawnych, lekarzy). Wraz z otwarciem samorzadów zawodowych na możliwość prowadzenia praktyki w ramach innych rodzajów spółek spółki jawne i partnerskie przestały się cieszyć zainteresowaniem wśród przedstawicieli wolnych zawodów. Można postawić tezę, że spółki komandytowe wydają się atrakcyjniejsze ze względu na ograniczona odpowiedzialność komandytariuszy (choć przedstawiciele wolnych zawodów nie mogą sprawować zazwyczaj innej funkcji niż komplementariusza w sp.k.).

Poza zakresem odpowiedzialności wspólników, spółki komandytowe i komandytowo-akcyjne różnią się od spółki jawnej (partnerskiej) sposobem przekształcenia w inną spółkę osobową. Do przekształcenia wymaga się sporządzenia planu przekształcenia, powzięcia uchwały o przekształceniu, powołania członków organu spółki przekształcanej (albo określenia wspólników prowadzących sprawy tej spółki i reprezentujących ją), zawarcia umowy spółki przekształconej, dokonania w rejestrze wpisu spółki przekształconej i wykreślenia spółki przekształcanej. Plan przekształcenia należy poddać badaniu przez biegłego rewidenta $^{8}$ co do rzetelności i prawidłowości tego planu. Dodatkowo powinno mieć miejsce podwójne zawiadomienie wspólników o zamiarze podjęcia uchwały o przekształceniu (w odstępie nie krótszym niż dwa tygodnie i nie później niż na miesiąc przed planowanym dniem podjęcia tej uchwały). W myśl art. 558 § 2 pkt. 3 i 4 k.s.h. załącznikami do planu przekształcenia są: wycena składników majątku (aktywów i pasywów) spółki przekształcanej, sprawozdanie finansowe sporzadzone dla celów przekształcenia na określony dzień w miesiącu poprzedzającym przedłożenie wspólnikom planu przekształcenia przy zastosowaniu takich samych metod i w takim samym układzie, jak ostatnie roczne sprawozdanie finansowe spółki. Wspomniane wymagania formalne przewidziane w Kodeksie spółek handlowych w stosunku do przekształcenia spółki komandytowej w inną spółkę osobową maja charakter norm ius cogens i nie mogą być ograniczone lub wyłączone na podstawie woli stron (wspólników).

Dokonując krótkiej komparatystyki obu wspomnianych procesów, należy zauważyć, że w przypadku uproszczonego przekształcenia brak jest obowiązku sporządzania opinii przez biegłego rewidenta co do rzetelności i prawidłowości planu przekształcenia, zawiadamiania wspólników (także przedstawienia im ustnie istotnych elementów dokumentów wymienionych w art. 561 $\S 1$ k.s.h.). Pozwala to wspólnikom przeprowadzić proces w sposób szybki i mniej kosztowny (nie trzeba ponosić kosztu wynagrodzenia biegłego rewidenta). Jeśli wszyscy wspólnicy wyrażają zgodę na uczestnictwo w spółce przekształconej, to oznacza, że zapoznali sie z projektami uchwał o przekształceniu oraz umowy spółki przekształcanej. Pełna akceptacja dla przekształcenia jest w pełni pożądana, gdyż modyfikacja formy prowadzonej działalności należy do jednej $\mathrm{z}$ najbardziej istotnych zmian podczas trwania spółki. Dzieje się tak ze względu na fakt, że dotychczasowi wspólnicy otrzymują nowe prawa, a ich katalog obowiązków ulega znacznej zmianie. 


\section{Skutki podatkowe w świetle ustawy o podatku od towarów i usług}

Zgodnie $\mathrm{z}$ art. 1 ustawy o $\mathrm{PCC}^{9}$ nie podlegają podatkowi od czynności cywilnoprawnych te czynności, które zostały opodatkowane na gruncie VAT. Podobna sytuacja zaistnieje w stosunku do czynności podlegających VAT - nie powinny być opodatkowane PCC, także jeśli podatnik VAT czynny (spółka) jest zwolniony przedmiotowo lub podmiotowo (Krawczyk, 2001, s. 34-36). Wyjątkiem jest sytuacja, w której strony umowy dokonają sprzedaży lub zamiany, której przedmiotem jest nieruchomość lub jej część, albo prawo użytkowania wieczystego, spółdzielcze własnościowe prawo do lokalu, prawo do domu jednorodzinnego w spółdzielni mieszkaniowej lub prawo do miejsca postojowego w garażu wielostanowiskowym lub udział w tych prawach (także jeśli mieć będzie miejsce sprzedaż udziałów i akcji spółek prawa handlowego). W procesie przekształcenia nie dochodzi do czynności zbycia towarów, wykonania usługi bądź przeniesienia własności. Jeśli wspólnicy chcieliby zmniejszyć majątek (np. wycofując część z wniesionych do spółki wkładów) spółki przekształcanej, to powinni to uczynić przed podjęciem uchwały o przekształceniu. Po stworzeniu planu przekształcenia i podjecciu uchwały rozporządzanie majątkiem spółki doprowadzi do sytuacji, w której struktura przedsiębiorstwa spółki (oraz jego wycena) będzie różna $\mathrm{w}$ planie przekształcenia $\mathrm{i} \mathrm{w}$ umowie spółki. Przyjmując jednak wzorcowy charakter przekształcenia, majątek spółki przekształcanej staje się ex lege majątkiem spółki przekształconej. Tym samym nie następuje m.in. wyprowadzenie $\mathrm{z}$ przedsiębiorstwa pierwotnego podmiotu składników majątkowych i wprowadzenie ich do spółki przekształconej. Zmiany formy nie należy interpretować jako przykładu czynności opodatkowanej podatkiem od towarów i usług 10 .

\section{Konsekwencje przekształcenia na gruncie PCC}

Zmiana formy prawnej spółki osobowej w osobową - co do zasady - powoduje powstanie obowiązku podatkowego po stronie spółki na gruncie podatku od czynności cywilnoprawnych. Stawka podatku w tym przypadku wynosi $0,5 \%$, zaś podstawa opodatkowania uzależniona jest od wartości wkładów do spółki osobowej powstałej w wyniku przekształcenia (art. 6 i 7 ustawy o PCC). Od podstawy opodatkowania odlicza się kwotę wynagrodzenia notariusza wraz z VAT, opłatę sądową związaną z wpisem zmiany do Rejestru Przedsiębiorców Krajowego Rejestru Sądowego, opłatę za ogłoszenie w Monitorze Sądowym i Gospodarczym zmiany wpisu w KRS. Należy uznać, że ustawodawca wyłączył przy tym zastosowanie ustawy o podatku od czynności cywilnoprawnych do zmian umowy spółki osobowej w przedmiocie przekształcenia w inną spółkę osobową, gdy w związku z tym procesem nie zwiększa się majątek spółki przekształconej (vide art. 1 ust. 3 pkt. 3 ustawy o PCC) ${ }^{11}$. W świetle art. 28 k.s.h. majątkiem spółki jest mienie wniesione jako wkład lub nabyte w trakcie istnienia spółki. Dlatego też jeśli w trakcie procesu wartość majątku ulegnie podniesieniu, np. wskutek dołaczenia nowego wspólnika i wniesienia przez niego aportu, to powstanie wartość nieopodatkowana uprzednio PCC. Różnica pomiędzy zwiększonym majątkiem a wartością pierwotną (przed podjęciem uchwały wspólników o przekształceniu) jest podstawą opodatkowania na gruncie podatku od czynności cywilnoprawnych. Zdaniem niektórych jest to przesłanka bezprzedmiotowa, gdyż zwiększenie majątku w trakcie przekształcenia nie jest możliwe (Kuniewicz, 2010, s. 29-31; Litwińczuk, 2001, s. 6-8). Takie twierdzenie wydaje się nie w pełni uprawnione. W szczególności trudność może sprawić interpretacja stosownych momentów, w których należy porównać majątek spółki przekształcanej ze spółką przekształconą. Jednym z rozwiązań jest porównanie wysokości wkładów do spółki przekształcanej, wniesionych w momencie powstania spółki (a także podczas jej trwania) z wysokością wkładów, które wprowadzają wspólnicy spółki przekształconej.

W piśmiennictwie (Goettel i Goettel, 2007, s. 118-119, Waluga, 2007, s. 86-88; Zdanowicz, 2009, s. 30; 32) podnosi się także, że ustawodawca, konstruując art. 1 ust. 3 pkt. 3 ustawy o PCC, miał na uwadze wszystkie procesy restrukturyzacyjne spółki (dotyczące zmian jej podmiotowości prawnej), określane jako przekształcenia sensu largo. Uzasadniać miałoby to użycie we wspomnianym artykule wyrażenia 
„przekształcenie lub łączenie spółek”. Taki pogląd nie wydaje się jednak właściwy w kontekście art. 2 pkt. 6 ustawy o PCC, gdyż w ustawie o PCC zawarto oddzielne uregulowania odnoszące się do podziału, łączenia spółek lub wniesienia przedsiębiorstwa do spółki. Oznacza to, że wszystkie czynności, wskutek których następuje zmiana umowy spółki, zostały określone w taki sposób, jaki ma to miejsce w Kodeksie spółek handlowych. Tym samym teza o możliwości stosowania wykładni rozszerzającej art. 1 ust. 3 pkt. 3 ustawy o PCC jest nieprawidłowa. Jednocześnie nie stoi to na przeszkodzie, aby uznać za przejrzysty podatkowo na gruncie podatku od czynności cywilnoprawnych proces przekształcenia spółki osobowej w inną osobową wtedy, gdy zwiększeniu nie ulega majątek spółki przekształcanej.

Warto przy tym nadmienić, że Komisja Europejska postuluje zniesienie podatku od działań restrukturyzacyjnych także w stosunku przekształcenia spółki osobowej w kapitałową (preambuła Dyrektywy Rady 2008/7/WE z dnia 12 lutego 2008 r. dotycząca podatków pośrednich od kapitałów ${ }^{12}$ ). W sposób obszerny odnoszą się do tego sądy administracyjne ${ }^{13}$, wedle których nakładanie na spółki osobowe jakichkolwiek podatków pośrednich z tytułu przekształcenia w rozumieniu sensu stricto jest niezgodne z treścią preambuły ww. Dyrektywy. Państwa członkowskie powinny dążyć do zniesienia wszelkich podatków związanych ze zmianą formy prowadzonej działalności ze spółki osobowej w inną spółkę prawa handlowego. Bezpodstawne wydaje się stosowanie wykładni rozszerzającej art. 1 Dyrektywy 2008/7/WE w taki sposób, aby przekształcenie każdej spółki osobowej poczytywać jako „restrukturyzację spółki kapitałowej”. Nie można godzić się z wymiennym stosowaniem tautologii prawniczej, gdyż oznaczałoby to pominięcie definicji legalnych zawartych zarówno $\mathrm{w}$ prawie podatkowym, jak i innych dziedzinach prawa (np. handlowego) pośrednio mających wpływ na opodatkowanie przekształceń.

\section{Przekształcenie a podatek dochodowy}

Przepisy ustawy o podatku dochodowym od osób fizycznych ${ }^{14}$ nie zawierają postanowień szczególnych, który mogłyby być podstawą opodatkowania czynności przekształcenia spółki osobowej w inną spółkę osobową na gruncie PIT. Artykuł 10 p.d.o.f., który zawiera katalog źródeł przychodu, nie obejmuje swoim zakresem tego typu procesu. Jeśli dotychczasowi wspólnicy nie uzyskają (w związku z przekształceniem) nowych praw lub nie otrzymają świadczeń pieniężnych wypłaconych np. $\mathrm{z}$ tytułu rekompensaty za ograniczenie możliwości podejmowania decyzji za spółkę (w razie zmiany statusu wspólnika sp.j. na komandytariusza sp.k.), to przychód nie powstanie po ich stronie. Jeśli przed zakończeniem procesu przekształcenia powstał zysk po stronie spółki przekształcanej i nie został on pozostawiony do dyspozycji wspólników, to rejestracja spółki przekształconej nie powoduje wypłaty akumulowanego zysku i powstania obowiązku w zakresie podatku dochodowego od osób fizycznych ${ }^{15}$. W spółce przekształconej wspólnik posiada to samo prawo do zysku i jest tak samo opodatkowany jedynie podatkiem dochodowym od osób fizycznych.

Jeśli wspólnicy spółki osobowej w trakcie przekształcenia dokonają przeniesienia wartości wniesionych wkładów do spółki przekształcanej na kapitał zakładowy spółki komandytowo-akcyjnej, to nie wystąpi przychód po stronie spółki przekształconej (lub jej wspólników). Mimo że w odróżnieniu od pozostałych spółek osobowych spółka komandytowo-akcyjna posiada instytucje kapitału zakładowego (w trakcie przekształcenia jest on pokrywany z majątku spółki przekształcanej), to dopiero jego podwyższenie o środki znajdujące się na kapitale zapasowym spółki przekształcanej może być kwalifikowane jako rozdysponowanie zysku spółki przez wspólników (obowiązek zapłaty podatku dochodowego) art. 24 ust. 5 pkt. 4 p.d.o.f.

Spółki osobowe, z wyjątkiem spółki komandytowo-akcyjnej, nie są opodatkowanie podatkiem dochodowym od osób prawnych ${ }^{16}$. Warto jednak nadmienić, że także w świetle art. 12 ustawy o CIT nie można kwalifikować przekształcenia spółki kapitałowej w inną spółkę kapitałową jako czynność skutkującą powstaniem przychodu po stronie spółki lub wspólników. Jeśli wspólnicy nie otrzymują żadnego przysporzenia $\mathrm{w}$ związku $\mathrm{z}$ przekształceniem, to bezpodstawne wydaje się twierdzenie, jakoby wspólnicy ci otrzymywali nowe prawa majątkowe. Warto przy tym 
przyznać, że wartość niepodzielonego zysku w spółce przekształcanej (art. 10 ust. 1 pkt. 8 ustawy o CIT) oraz podwyższenie kapitału zakładowego z środków zgromadzonych na kapitale zapasowym (art. 10 ust. 1 pkt. 4 ustawy o CIT) spółki przekształconej stanowi przychód podatkowy dla spółki. Obecnie trwa dyskusja ${ }^{17}$ co do sposobu i charakteru opodatkowania spółek komandytowo-akcyjnych. Nie mniej wątpliwości może wzbudzać sposób sukcesji praw i obowiązków wspólników w związku $\mathrm{z}$ procesem przekształcenia.

\section{Sukcesja praw i obowiązków podatkowych}

Aby określić charakter sukcesji podatkowej przekształcenia spółki osobowej w osobowa, należy odnieść się do postulatu homogeniczności procesu przekształcenia. Wedle tej tezy przekształcenie homogeniczne nie skutkuje zmianą osoby podatnika, prawa i obowiązki podatkowe sa takie same dla spółki przekształconej i przekształcanej ponieważ jest to ten sam podmiot ${ }^{18}$. Dlatego też jeśli spółki osobowa jest właścicielem nieruchomości lub gruntów rolnych, to spółka przekształcona staje się podatnikiem w zakresie tych podatków, począwszy od pierwszego dnia miesiaca nastepującego od dokonania rejestracji spółki przekształconej (wpis w księdze wieczystej ma w tej sytuacji charakter deklaratoryjny).

W myśl art. 93a § 2 Ordynacji podatkowej ${ }^{19}$ osobowa spółka prawa handlowego w wyniku przekształcenia wstępuje we wszelkie przewidziane w przepisach prawa podatkowego prawa i obowiazki przekształcanej spółki. Niekiedy stawiana jest teza, że w prawie prywatnym przy przekształceniu spółki ma miejsce kontynuacja, zaś w prawie podatkowym - sukcesja praw i obowiązków ${ }^{20}$. Kontynuacja praw to pozostawanie w tym samym kształcie (co dotychczas) praw i obowiązków spółki. Sukcesja jest przeniesieniem (ex lege) praw i obowiązków na nowy podmiot, tj. spółka przekształcana przekazuje spółce przekształconej przedmiotowe prawa o charakterze obligacyjnym. Tym samym, skoro jest mowa w art. 93 i 93a OP o wstepowaniu nowego podmiotu w prawa podmiotu przekształcanego, to oznacza to sukcesje praw (przejście). Ciekawa wydaje się teza o selektywności praw i obowiazków, które moga być przedmiotem sukcesji. Rozumując a contrario: na nowy podmiot przechodzą jedynie te prawa i obowiązki, których sukcesja nie została wyłączona w drodze decyzji administracyjnej na podstawie $553 \S 2$ k.s.h. ${ }^{21}$. Jeśli założymy, że spółce przekształcanej została - w drodze decyzji podatkowej - udzielona ulga podatkowa, to organ podatkowy ma w odniesieniu do spółki przekształconej prawo do wydania nowej decyzji uchylającej decyzję pierwotną o przyznanie ulgi. Nie wydaje się tutaj prawidłowe zastosowanie wygaśnięcia decyzji lub wszczęcie postanowienia $\mathrm{w}$ przedmiocie stwierdzenia nieważności decyzji o przyznanej uldze podatkowej. Pogląd o sukcesji generalnej (wstąpieniu spółki przekształconej w sytuację prawną spółki przekształcanej) należy przeciwstawić twierdzeniu o braku powstania nowego podmiotu. Skutkiem przekształcenia jest zmiana formy prawnej podmiotu, który nawet na moment nie zawiesza swojej działalności. Dlatego też, jeśli jest to ten sam podmiot (zachowuje także NIP, numer REGON, rachunek bankowy), to prawa i obowiązki nie ulegają przeniesieniu, lecz pozostają w sposób niezmienny przy podmiocie (mimo że po zarejestrowaniu spółki przekształconej jego forma prawna ulega zmianie). W zakres obowiązków spółki przekształcanej wchodzą także zobowiązania, które zostały zaciągnięte przed przekształceniem spółki osobowej.

Wspólnicy spółki osobowej odpowiadaja ze spółką przekształconą za zobowiązania powstałe przed dniem rejestracji przekształcenia w KRS, przez okres trzech lat od tego dnia. Kontynuacja dotyczy zatem nie tylko praw i obowiązków spółki, ale w niektórych przypadkach - także wspólników spółki przekształcanej. Nie jest to odpowiedzialność subsydiarna, tj. można dochodzić spłaty zobowiązania od razu do jednego z wspólników (bez uprzedniego skierowania się do majątku spółki przekształconej) (Pawłyszcze, 2004, s. 25-27; Stepień, 2006, s. 29-32, Witosz, 2005, s. 3-6). Tym samym wspólnicy mogą być obciążeni odsetkami za zwłokę od zaległości podatkowych, kosztami postępowania egzekucyjnego, niezwróconymi w terminie zaliczkami naliczonego podatku od towarów i usług. Wspólnicy traktowani sa w świetle art. 107 OP i następnych - jako osoby trzecie, wobec których musi być prowadzone postępowanie podatkowe i musi być wydana odrębna decyzja. Stwierdzić należy, że organ podatkowy może zwrócić 
się do danego dłużnika solidarnego, jednak wcześniej musi przeprowadzić postępowania podatkowe wobec wszystkich zobowiązanych.

\section{Podsumowanie}

Przekształcenie jest zmianą formy prawnej danej spółki, wskutek czego nie powstaje nowy (odrębny) podmiot. Chociaż wspólnicy wraz z rejestracją spółki przekształconej zaczynają podlegać nowym przepisom prawa handlowego (dla danego rodzaju spółki), to mają inną pozycję niż udziałowcy spółki tego samego typu stworzonej od podstaw. Na gruncie prawa cywilnego, prawa pracy następuje kontynuacja praw i obowiązków dotychczasowego podmiotu na nowo utworzony (Stępień, 2006, s. 24-27; Sokal, 2005, s. 58-59). Można przyjąć tezę, że przekształcenie spółki osobową w inną spółkę osobową jest transparentne podatkowo, jeśli wspólnicy wyrazili zgodę o uczestnictwie w spółce przekształconej, swoim działaniem nie powodują podwyższenia majątku spółki w trakcie procesu i nie zmieniają partycypacji udziału w zysku spółki. Podatek od towarów i usług nie wystąpi, gdyż nie jest dokonywana sprzedaż towarów lub świadczenie usług przez wspólników czy spółkę. Wspólnicy (jeśli nie zwiększają swoich udziałów) nie mają powodów do uiszczenia podatku dochodowego, gdyż obowiązek w tym podatku nie powstaje. Podobnie w odniesieniu do podatku od czynności cywilnoprawnych, który występuje jedynie wtedy, gdy wskutek przekształcenia następuje zwiększenie majątku spółki przekształcanej. W odniesieniu do odpowiedzialności podatkowej należy stwierdzić, że wspólnicy spółki osobowej mają gorszą sytuację prawną jako dłużnicy solidarni (odpowiadający za zobowiązania spółki przekształcanej do 3 lat od chwili rejestracji przekształcenia) w stosunku do tego, jakie ramy ich odpowiedzialności występowały w spółce pierwotnej (odpowiedzialność subsydiarna). Przy przekształcaniu spółki osobowej w inną spółkę osobową (za wyjątkiem spółki komandytowo-akcyjnej), nie ulega poszerzeniu krąg podatków bezpośrednich jakie występują w spółce przekształconej (wspólnicy podlegaja jedynie opodatkowaniu podatkiem dochodowym od osób fizycznych).

Kończac, należy zwrócić uwage na potrzebę niezbędnych zmian w zakresie ustawy o podatku od czynności cywilnoprawnych - przepisów odnoszących się do przekształcenia spółki osobowej w osobową. Ustawodawca winien w sposób jednoznaczny wprowadzić konstrukcję zwolnienia w PCC czynności wspomnianego przekształcenia (postulat de lege ferenda). Wspólnicy spółki, przy podpisywaniu aktu erekcyjnego spółki osobowej uiścili podatek od czynności cywilnoprawnych. Dlatego też nie ma podstaw, aby ponownie opodatkowywać ich PCC z tytułu sporządzenia umowy spółki przekształconej - gdyż jest to ten sam podmiot praw i obowiązków co spółka przekształcana.

\section{Przypisy}

1 Spółki kapitałowe jako osoby prawne mają swobodne prawo domicylu, mogą wybierać miejsce siedziby (Opalski, 2009, s. 67). Cytowana publikacja nie dotyczy spółek, w których udział ma Skarb Państwa, a jedynie podmiotów prywatnych. Szerzej o przekształceniach (zmianach) w obrębie finansów publicznych - zob. Kosikowski (2010, s. 83-174).

2 Błystak (2008, s. 6-8); Lewicki (2003, s. 25); Gajewski (2001, s. 11); Gajewski (2001, s. 11); Szubielska i Kozaczuk (1998, s. 4). Interpretacja indywidualna $\mathrm{z}$ dnia 14 czerwca 2013 r. Dyrektora Izby Skarbowej w Warszawie, IPPB2/436-233/13-2/MZ; Interpretacja indywidualna z dnia 4 czerwca 2013 r. Dyrektora Izby Skarbowej w Warszawie, IPPB2/436-170/13-4/ AF, Interpretacja indywidualna $\mathrm{z}$ dnia 13 grudnia 2002 r. Dyrektora Izby Skarbowej w Warszawie, IPPB2/436-473/12-4/AF. Instytucja przekształcenia spółki handlowej w inną spółkę została recypowana do porządku prawnego Polski po I wojnie światowej z ustawodawstwa austriackiego i pruskiego (Miś, 2005, s. 47). Po raz pierwszy ustawodawca wprowadził przekształcenia (spółek kapitałowych) wraz z wejściem w życie Rozporzadzenia Prezydenta Rzeczypospolitej Polskiej z 27.06.1934 r. - Kodeks handlowy (Dz. U. 1934, Nr 57, poz. 502 ze zm.).

3 Por. Pietrasiewicz (w: Litwińczuk, 2013, s. 267); Materna (2009, s. 54) i Klimkiewicz (2011, s. 322). W stosunku do przekształcenia sensu largo używa się także sformułowania „czynności, restrukturyzacyjne” (Witosz, 2003, s. 34-36; Grzybek, 2014, s. 141-149).

4 Ustawa z dnia 15 września 2000 r. Kodeks spółek handlowych (Dz. U. 2013, poz. 1030, j.t.), zwana także k.s.h.

5 Autor użył celowo uogólnienia, aby nie wdawać się w dysputę na temat możliwych różnic wnoszenia wkładów niepieniężnych w spółkach kapitałowych i osobowych. 
6 Spółkę cywilną można przekształcić w spółkę osobowa, stosujac odpowiednio przepisy o przekształceniu spółki jawnej w inną spółkę osobową - art. 551 § 3 k.s.h. Spółce przekształconej przysługują wszelkie prawa i obowiązki wspólników sp.c.

7 Podjęcie uchwały wszystkich wspólników o przekształceniu w inną spółkę należy dodatkowo usankcjonować poprzez pisemne oświadczenie wspólników o uczestnictwie w spółce przekształconej. Rezygnacja wspólnika spółki po podjęciu tejże uchwały jest możliwa, jednak powoduje nieskuteczność uchwały o uczestnictwie w odniesieniu do innych wspólników, per analogiam (Kozieł, 2008, s. 96). Wydaje się, że art. 582 k.s.h. (mimo wąskiego zakresu sytuacji do których ma odniesienie) został pod względem legislacyjnym prawidłowo skonstruowany, przeciwnie: Witosz (2007, s. 2-4).

8 Wyznaczenie biegłego rewidenta dokonywane jest w formie postanowienia przez Sąd Rejestrowy właściwy dla siedziby spółki. Wnioskodawcą jest spółka, która może wskazać danego biegłego rewidenta do badania w zakresie przekształcenia spółki (wymagane jest załączenie oświadczenia biegłego rewidenta o wyrażeniu zgody na podjęcie się przedmiotowego badania). Jeśli spółka tego nie dokona, Sąd zwróci się do Krajowej Izby Biegłych Rewidentów o wyznaczenie przez izbe osoby biegłego rewidenta. Szerzej: Miroszewski (2002, s. 32-35).

9 Ustawa z 9.09.2000 r. o podatku od czynności cywilnoprawnych (Dz. U. 2010, Nr 101, poz. 649, j.t.) - dalej ustawa o PCC. Ustawa Z dnia 11.03.2004 r. o podatku od towarów i usług (Dz. U. 2011, Nr 177, poz. 1054) - zwana dalej ustawą o VAT.

10 Por. Interpretacja indywidualna $\mathrm{z}$ dnia 11 grudnia 2002 r. Dyrektora Izby Skarbowej w Lodzi, IPTPP1/443-777/12-4/MG; Interpretacja indywidualna z dnia 24 lipca 2012 r. Dyrektora Izby Skarbowej w Warszawie, IPPP2/443-452/12-2/IG.

11 Por. wyrok WSA w Gorzowie Wielkopolskim z dnia 19 stycznia 2011 r., I SA/Go 984/2010; interpretacja indywidualna Dyrektora Izby Skarbowej w Warszawie z dnia 20 stycznia 2012 r., sygn. IPPB2/436-503/11-3/MZ; Interpretacja indywidualna Dyrektora Izby Skarbowej w Łodzi z dnia 7 lipca 2011 r., sygn. IPTPB2/436 -37/11-2/k.k.

12 Dyrektywa Rady 2008/7/WE z dnia 12 lutego 2008 dotyczaca podatków pośrednich od kapitałów (Dz.U.UE.L. 2013, Nr 141, poz. 30) dalej Dyrektywa 2008/7/WE. Obecnie jedynie siedem państw członkowskich nakłada tenże podatek (inne zaś nakładają obciążenia podatkowe na przedsiębiorców w innej formie), Opinia Europejskiego Komitetu EkonomicznoSpołecznego w sprawie wniosku dotyczącego dyrektywy Rady dotyczącej podatków pośred- nich od gromadzenia kapitału (Dz.U.UE.C 2007, Nr 161, poz. 23).

13 Wyrok Wojewódzkiego Sądu Administracyjnego w Krakowie z dnia 10 stycznia 2013 r., I SA/ Kr 895/12; wyrok Wojewódzkiego Sądu Administracyjnego w Gorzowie Wielkopolskim z dnia 27 czerwca 2013 r., I SA/Go 236/13.

14 Ustawa z dnia 26 lipca 1991 r. o podatku dochodowym od osób fizycznych (Dz. U. 2012, poz. 361, j.t.) - zwana dalej p.d.o.f. Podatek dochodowy od osób fizycznych zwany także PIT. O opodatkowaniu tego rodzaju przekształcenia w kontekście podatku dochodowego pisze m.in. Sobiech (2014, s. 125-135).

15 Interpretacji indywidualna Dyrektora Izby Skarbowej w Łodzi z 16 lipca 2013 r., sygn. IPTPB1/415-301/13-2/MAP; Interpretacja indywidualna Dyrektora Izby Skarbowej w Łodzi z dnia 31 października 2012 r., sygn. IPTPB3/423-271/12-5/GG; Interpretacja indywidualna Dyrektora Izby Skarbowej w Katowicach z dnia 7 października 2012 r. sygn. IBPBII/2/415-542/12/MMa. Odmienna sytuacja występuje w odniesieniu do przekształcenia spółki kapitałowej w osobowa, gdzie opodatkowaniu powinno ulec zgromadzone środki na kapitale zapasowym - art. 24 ust. 5 pkt. 8 p.d.o.f.

16 Ustawa z dnia 15 lutego 1992 r. ustawy o podatku dochodowym od osób prawnych (Dz. U. 2011, Nr 74, poz. 397). Podatek dochodowy od osób prawnych - dalej zwany CIT.

17 Budziszewski (2013, s. 48); Brzeziński (2011, s. 19); Golec (2012, s. 6). Zdaniem organów podatkowych, przekształcenie spółki kapitałowej w inną kapitałową nie rodzi obowiązku podatkowego w zakresie CIT-interpretacja indywidualna Dyrektora Izby Skarbowej w Warszawie z dnia 19 sierpnia 2009 r., IPPB3/423-341/09-4/AG.

18 Por. Karczyński (2011, s. 153-155); Radzikowski (2009, s. 4-8); Mariański (2003, s. 50-51); Grzybek (2014, s. 11-31).

19 Ustawa z dnia 29 sierpnia 1997 r. Ordynacja podatkowa (Dz. U. 2007, poz. 749, j.t.). Generalny charakter tego przepisu sprawia czasem trudności interpretacyjne (Karczyński, 2009, s. 21-23). Należy przy tym stwierdzić, że ustawodawca celowo pominął wyjątki od tej zasady - co pozwala stosować wykładnię rozszerzającą, korzystniejszą dla podatnika, por. Smoktunowicz (1997, s. 11) i Swiderek (2007, s. 136-138).

20 Boryczko i Piotrowski (1998, s. 8); Huchla (w: Brzeziński i Kosikowski, 1999, s. 148). Zdaniem Sądu Apelacyjnego w Poznaniu, w przypadku kontynuacji nie ma poprzednika i następcy prawnego, ale istnieje ta sama spółka w zmienionej formie, wyrok z dnia 12 września 2013 r., I ACz 1170/13; Litwińczuk (w: Mastalski, 2001, s. 37). Odmienny pogląd wyrażają Kozaczuk, i Szubielska (1998, s. 12-14) i Mariański (1999, s. 7; 9). 
21 Przeciwnie Sąd Apelacyjny w Łodzi, wyrok z dnia 11 października 2012 r., I Aca 620/12 oraz Naczelny Sąd Administracyjny, wyrok z dnia 17 kwietnia 2009 r., II GSK 71/09.

\section{Bibliografia}

Błystak, Z. (2008). Zyski przekształcanej spółki kapitałowej nie podlegają opodatkowaniu w dacie przekształcenia. Jurysdykcja Podatkowa, 5.

Boryczko, E. i Piotrowski, M. (1998). Następstwo prawne w przepisach podatkowych w świetle regulacji cywilnoprawnych - wybrane zagadnienia, cz. II. Doradztwo Podatkowe, 2.

Budziszewski, J. (2013). Opodatkowanie przychodów (dochodów) akcjonariusza spółki komandytowo-akcyjnej. Doradztwo Podatkowe, 11.

Brzeziński, B. (2011). Pytanie prawne w sprawie opodatkowania akcjonariusza spółki komandytowoakcyjnej - czy odpowiedź usatysfakcjonuje podatników? Prawo i Podatki, 5.

Brzeziński, B. i Kosikowski, C. (1999). Studia nad Ordynacja podatkowa. Łódź-Toruń.

Gajewski, D. (2001). Wybrane aspekty podatkowe przekształceń spółek kapitałowych. Monitor Podatkowy, 8 .

Golec, S. (2012). Opodatkowanie podatkiem dochodowym akcjonariuszy spółki komandytowoakcyjnej - zagadnienia problemowe. Przeglad Podatkowy, 6 .

Goettel, M. i Goettel, A. (2007). Podatek od czynności cywilnoprawnych. Komentarz. Warszawa.

Grzybek, O. (2014). Przekształcenia spółek handlowych w świetle konsekwencji podatkowych. Zeszyty Naukowe US. Finanse, rynki finansowe, ubezpieczenia, 68.

Grzybek, O. (2014). Przekształcenia spółki kapitałowej w spółkę osobową w polskim prawie handlowym i bilansowym. Prace Naukowe Uniwersytetu Ekonomicznego w Katowicach.

Karczyński, Ł. (2009). Kilka uwag o interpretacji terminów „przepisy prawa podatkowego” i „ustawa podatkowa" na gruncie Ordynacji podatkowej. Monitor Podatkowy, 7.

Karczyński, Ł. (2011). Opodatkowanie przeksztatceń spótek. Warszawa.

Kosikowski, C. (red.) (2010). System prawa finansowego, t. I. Warszawa.

Kozaczuk, M. i Szubielska, D. (1998). Fuzje zagadnienia podatkowe i bilansowe. Przeglad Podatkowy, 2.

Kozieł, G. (2008). Członkostwo w handlowej spółce osobowej a przekształcenie spółek. Państwo i Prawo, 9.

Klimkiewicz, K. (red.). Restrukturyzacje spótek kapitałowych. Warszawa.
Krawczyk, I. (2011). Podatek od czynności cywilnoprawnych a VAT. Przegląd Podatkowy, 5.

Kuniewicz, Z. (2010). Interpretacyjne dylematy ustalenia konsekwencji podatkowych przekształcenia lub połączenia spółek. Przegląd Prawa Handlowego, 6.

Litwińczuk, H. (2001). Przekształcenia spółek aspekty podatkowe. Przeglad Prawa Handlowego, 5. Lewicki, A. (2003). Przekształcenie spółki z o.o. w spółkę osobową - aspekty podatkowe. Glosa, 9 .

Litwińczuk, H. (red.) (2013). Prawo podatkowe przedsiębiorców. Warszawa.

Mariański, A. (2003). Sukcesja praw i obowiązków publicznoprawnych - rozważania na tle art. 494 par. 3 i 5 k.s.h. - polemika. Przeglad Prawa Handlowego, 12.

Mariański, A. (1999). Sukcesja generalna czy odpowiedzialność osoby trzeciej. Przeglad Podatkowy, 3 .

Mastalski, R. (red.) (2001). Księga jubileuszowa Profesora Marka Mazurkiewicza. Studia z dziedziny prawa finansowego, prawa konstytucyjnego i ochrony środowiska. Wrocław.

Materna, G. (2009). Pojęcie przedsiębiorcy $w$ polskim i europejskim prawie ochrony konkurencji. Warszawa.

Miroszewski, L. (2002). Wyznaczenie biegłego rewidenta w procesie przekształcenia spółki. Przegląd Prawa Handlowego, 8

Miś, G. (2005). Przeksztatcenie spótek handlowych. Warszawa.

Opalski, A. (2009). Swoboda osiedlania się spółek w świetle wyroku w sprawie Cartsio. Państwo i Prawo, 8.

Pawłyszcze, D. (2004). Wygaśnięcie odpowiedzialności za długi wspólników przekształconej spółki osobowej. Przeglad Prawa Handlowego, 9.

Radzikowski, K. (2009). Opodatkowanie podatkiem dochodowym wspólników osobowych spółek handlowych. Prawo i Podatki, 9.

Sokal, P. (2005). Znaczenie procesów restrukturyzacyjnych w spółkach handlowych a prawo zastawu. Prawo Spótek, 7-8.

Sobiech, A. (2014). Skutki podatkowe przekształcenia spółki komandytowo-akcyjnej w inną spółkę osobową. Zeszyty Naukowe US. Finanse, rynki finansowe, ubezpieczenia, 68.

Smoktunowicz, E. (1997). Analogia w prawie podatkowym, Glosa do wyroku NSA z 10 marca 1994 r. (SA/Ka 1857/93). Glosa, 3.

Stepień, A. (2006). Charakter prawny terminu z art. 574 Kodeksu spólek handlowych. Prawo Spótek, 5.

Stępień, A. (2006). Wpływ przekształcenia spółek handlowych na stosunek pracy. Praca $i$ Zabezpieczenie Spoteczne, 9. 
Szubielska, D. i Kozaczuk, M. (1998). Przekształcenia spółek kapitałowych - zagadnienia podatkowe. Przeglad Podatkowy, 3.

Świderek, Ł. (2007). Prawno-podatkowe skutk przekształcenia spółki. Wybrane regulacje, Rejent, 9 .

Waluga, M. (2007). Komentarz do ustawy o podatku od czynności cywilnoprawnych. Warszawa.

Witosz, A. (2007). Uzyskanie statusu komplementariusza przez jedynego komandytariusza w spółce komandytowej. Prawo Spótek, 10.
Witosz, A. (2003). Zaskarżanie uchwał restrukturyzacyjnych spółek handlowych w kodeksie spółek handlowych. Radca prawny, 2.

Witosz, A. (2005). Ograniczona w czasie odpowiedzialność łączącej się i przekształcanej spółki osobowej. Prawo Spótek, 7-8.

Zdanowicz, J. (2009). Podatek od czynności cywilnoprawnych. Optata skarbowa. Warszawa. 